\title{
Polythiacalix[4] amides as a Novel Category of Macromolecules; Synthesis, Antibacterial Evaluation and Investigation on their Spectral and Thermophysical Characteristics
}

\author{
Hamed Tashakkorian, ${ }^{1}$ Moslem Mansour Lakouraj, ${ }^{2, \star}$ Rahimeh Maldar $^{2}$ \\ and Zahra Moulana ${ }^{3}$ \\ ${ }^{1}$ Cellular and Molecular Biology Research Center (CMBRC), Health Research Institute, \\ Babol University of Medical Sciences, Babol, 4717641367, Iran \\ ${ }^{2}$ Department of Polymer Chemistry, Faculty of Chemistry, University of Mazanadaran, Babolsar, 47416 95447, Iran \\ ${ }^{3}$ Infectious Diseases \& Tropical Medicine Research Center, Babol University of Medical Sciences, Babol, 47176 41367, Iran \\ * Corresponding author: E-mail: lakouraj@umz.ac.ir \\ TelFax: (+) 98-1135302350
}

Received: 04-06-2017

\begin{abstract}
Polythiacalix[4]amides as a novel category of polyamides, with high sorption capability towards some environmentally hazardous metal cations, especially $\mathrm{Hg}^{2+}$, have been synthesized via direct polycondensation protocol using a thiacalix[4] arene dicarboxylic acid and commercial diamines. The polyamides were obtained in high yields and possess inherent viscosities in the range of $0.55-0.75 \mathrm{dl} / \mathrm{g}$. The photophysical characteristic was studied by looking for the maximum absorption wavelength of each polymer using UV absorption spectroscopy. Thermogravimetric analysis displayed high thermal stability for these polyamides in range of 337 to $346^{\circ} \mathrm{C}$ at the point of $10 \%$ weight loss, and their char yields were about $32.9-58.5 \%$ at $600{ }^{\circ} \mathrm{C}$. Also, glass transition temperatures were between 157 and $178{ }^{\circ} \mathrm{C}$. To survey on possible sorption capability of these polythiacalixamides, solid-liquid extraction of some toxic transition metal cations, such as $\mathrm{Cu}^{2+}, \mathrm{Co}^{2+}$, $\mathrm{Cd}^{2+}, \mathrm{Pb}^{2+}$ and $\mathrm{Hg}^{2+}$ from wastewater was performed. Antibacterial evaluation was conducted using Gram positive and Gram negative bacteria strains and some reliable results have been obtained. The results showed some promising features of their ability for being employed as possible ingredients of industrial antibacterial membranes.
\end{abstract}

Keywords: Supramolecular chemistry; Thiacalixarene; Antibacterial evaluation; Sorption capability; Thermal Stability; Polyamide

\section{Introduction}

In the last decade, scientists in the field of supramolecular chemistry have designed novel architectures of host molecules with which area of receptor chemistry has been developed. ${ }^{1-4}$ Supramolecules, such as cyclodextrins and crown ethers, calixarene and theirs derivatives including polycalixarenes have been employed widely in catalysis, ${ }^{5-8}$ molecular recognition or ion separation ${ }^{9,10}$ and as sensors $^{11-13}$ during recent years. Calixarenes structures provide interesting platforms for improving the reception capability of chemical structures by special modifications. Smart functionalization at the both upper and/or lower rim with specific complexing groups as well as replacement of $\mathrm{CH}_{2}$ bridge by oxygen or sulfur, can improve the ionic and molecular binding properties. Functionalization will increase the chance for recognition and separation of the target rare or toxic guests which is essential from economic and environmental point of view. For instance, sieving specific ions, such as $\mathrm{H}^{+}$and $\mathrm{Li}^{+}$or also attaching to the $\mathrm{Au}(111)$ single crystal surface are important strategies in energy conversion and storage systems and also in electrochemical applications, respectively. ${ }^{14}$ During the last decade, novel bioactive compounds with significant antibacterial and antifungal characteristics have emerged. 
Moreover, binding these bioactive compounds with platforms, such as calixarenes, has created the unique category of bioactive supramolecular compounds. These structures have noteworthy activities against cancerous cells and have demonstrated antibacterial and antifungal characteristics. ${ }^{15}$ One of the particular compounds of this family is called thiacalixarene, which has sulfur atoms instead of common methylene bridges and shows some surprising features of these macrocycles. Thiacalixarene and its derivatives display some unique properties which led them to be introduced in different applications from host-guest to supramolecular chemistry and also as molecular receptors. ${ }^{16-24}$ Based on the reported findings, these sulfur containing structures have attracted much attention in calixarene chemistry because of their usage in selective extraction of more polarizable transition metal ions instead of hard metal ions, such as alkali and alkaline earth cations. ${ }^{25-30}$

In macromolecular science, it has been proved that calixarene based ionophores have a great acceptability in modern chemistry because of their extreme capability in functionalization from bridge position up to both sides of the rims. As well, polymer scientists took advantage of these structures for preparation of ions-selective polymers or in producing efficient metal cations absorbent membranes. Furthermore, researchers who are studying the field of polymers focused their attention on the growing demands for novel antimicrobial compounds as major concerns for improving the standards of public health. Numerous strategies have been established to overcome the existence of medical device related infections. Therefore, preparations of polymeric materials containing antimicrobial moieties attracted much interest in recent years $^{31,32}$ and are commercially available in the forms of sutures, tubing, containers, films, dental implants, and catheters. As a part of our continuing study on the synthesis and physical properties of calixarene based polymers, ${ }^{33-36}$ the main goal of this research is to combine the extraction abilities towards heavy metal ions with antimicrobial properties by using thiacalixarene to introduce a novel type of polythiacalixamides. These high performance polyamides possess moieties with unique cavity size, thermal stability and also having acceptable antibacterial activities. We wish these polymers can be applied in polymeric antibacterial membranes which are being incorporated in environmental applications and also in medical devices.

\section{Experimental}

\section{1. Apparatus and Materials}

Melting points were determined on an Electro Thermal 9100 apparatus in a sealed capillary and are uncorrected. ${ }^{1} \mathrm{H}$ NMR spectra were recorded on a Bruker Avance III $400 \mathrm{MHz}$ spectrometer in $\mathrm{CDCl}_{3}$ and DMSO- $d_{6}$ with TMS as internal standard. IR spectra were recorded on a Bruker FTIR spectrometer as $\mathrm{KBr}$ pellets. For ultraviolet-visible (UV-Vis) measurements, Cecil'UV-Visible spectrophotometer was applied. Inherent viscosities of polymers were determined by using an Ostwald viscometer. Elemental analyses were performed by a CHN-O-Rapid Heraeus elemental analyzer (Wellesley, MA). Differential scanning calorimetry (DSC) and thermogravimetric analysis (TGA) were recorded on a Perkin-Elmer Pyris Diamond and Pyris 6 TGA Consumables, respectively. Thermo Fisher Scientific ICE 3300 Atomic Absorption Spectrometer (AAS) was employed for determination of the metal ions. All materials and reagents were of standard analytical grade, purchased from Fluka or Merck companies, and used without further purification. Commercial grade solvents such as acetone, acetonitrile, methanol, toluene and $n$-hexane were dried and stored over $4 \AA$ molecular sieves. ${ }^{37}$

\section{2. Synthesis}

The thiacalixarene dicarboxylic acid $\mathbf{3}$ and its precursors, compounds $\mathbf{1}$ and $\mathbf{2}$ were synthesized according to the literature procedures (Scheme 1). ${ }^{38-40}$ The FT-IR, ${ }^{1} \mathrm{H}$ NMR, and ${ }^{13} \mathrm{C}$ NMR spectral data and melting points of the prepared compounds were compared with the original data given in the corresponding articles. As illustrated in Scheme 2, the thiacalixarene-based polyamides A-D employed in this study were synthesized from condensation polymerization of thiacalixarene dicarboxylic acid with commercial diamines.

General Procedure for Polymerization of 5,11,17,23-Tetra-tert-butyl-25,27-bis-[carboxylmethoxy]-26,28-dihydroxy-2,8,14,20-tetrathiacalix[4]arene (3) with Commercial Diamines

A $25 \mathrm{~mL}$ two-necked, round-bottomed flask equipped with a reflux condenser, magnetic stirrer and gas inlet was charged with $1.2 \mathrm{mmol}$ of triphenylphosphite, 1 mmol pyridine and $5 \mathrm{~mL}$ of dry NMP. The solution was agitated at room temperature for 15 min under nitrogen atmosphere. Then, $1 \mathrm{mmol}$ of thiacalix[4]arene dicarboxylic acid $\mathbf{3}$ was added to the solution. After a few minutes, $1 \mathrm{mmol}$ of commercial diamine was dissolved in the reaction mixture. The temperature was raised to $110{ }^{\circ} \mathrm{C}$ and the solution stirred for $14 \mathrm{~h}$. Polythiacalixamide was produced during direct phosphorylation polymerization and precipitated by pouring the flask content into the cold methanol. After stirring for half an hour, it was filtered using Büchner funnel and washed with hot water and methanol, respectively. All of the polythiacalixamides mentioned in this work were prepared using the same procedure. The synthesized polymers were then dried overnight under vacuum at $120^{\circ} \mathrm{C}$ to afford corresponding polymers in $70-85 \%$ yields. The characteristic physical and spectral data of polythiacalixamides $\mathbf{A}-\mathbf{D}$ are given in Tables 1-3. 


\section{3. Survey on Transition Metal Removal using pTCAs}

Investigation on sorption behavior of polythiacalixamides (pTCAs) was carried out based on the following batch-wise procedure. pTCA $\left(25 \cdot 10^{-3} \mathrm{~g}\right)$ were added to 10 $\mathrm{mL}$ aliquot solution of the corresponding metal nitrate $\left(10 \cdot 10^{-3} \mathrm{~mol} \mathrm{~L}^{-1}\right)$. Then to have a precise comparison with our previously reported polycalixarenes (PCA), they were immersed in the test solutions and stirred at $25^{\circ} \mathrm{C}$ for $3 \mathrm{~h}$. After the specified time, pTCAs were filtered off and the concentrations of the remaining metal ions in the aqueous phase $\left(C_{\mathrm{e}}\right)$ were determined using atomic absorption spectroscopy. The percent sorption of ions $(S \%)$ and distribution coefficient $\left(K_{\mathrm{d}}\right)$ were calculated as:

$$
S \%=C_{i}-\frac{C_{e}}{C_{i}} \times 100
$$

$C_{\mathrm{i}}$ : Initial metal ion concentration

$$
K_{\mathrm{d}}=\frac{a / \mathrm{g} \text { of dry resin }}{B / \mathrm{mL} \text { of solution }}
$$

A: Amount of ion absorbed by resin

$B$ : Amount of metal remaining in solution

\section{4. Experimental Section: Determination of Antibacterial Activity}

Synthesized polymers and monomers containing 1,2,4-triazole units were evaluated for their anti-bacterial activity against microorganisms including the two Gram positive bacteria Staphylococcus aureus (ATCC 259230) and Bacillus subtilis (PTCC 1156) and three Gram negative bacteria: Escherichia coli (PTCC 1533), Pseudomonas aeruginosa (PTCC 1707) and Klebsiella pneumoniae (ATCC 11296). These common Gram positives and Gram negatives bacteria were investigated at different concentrations of the tested compounds using broth microdilution procedure. The compounds sensitivity of the strains was assayed for positive or negative growth after $24-48 \mathrm{~h}$. The MIC test was repeated at least three times for each antimicrobial agent. Then antibacterial activities of the compounds were compared with known and effective antibiotics penicillin, ciprofloxacin, and gentamicin at the same concentration.

\section{4. 1. Minimum Inhibitory Concentration (MIC)}

MIC is the lowest concentration which can cause complete growth inhibition. The broth microdilution method was applied to evaluate the $\mathrm{MIC}^{41} 100 \mu \mathrm{L}$ of

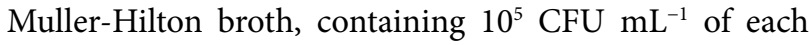
bacterium, was added to each well. $100 \mu \mathrm{L}$ of polythiacalix amide solutions with the maximum starting concentra- tions $500 \mu \mathrm{g} / \mathrm{mL}$ were poured in the first well of 96 sterilized well micro plates and then diluted to half concentrations in the next wells, respectively. After dilution micro plates were incubated at $37^{\circ} \mathrm{C}$ for $24 \mathrm{~h}$. The first well which was completely transparent and had no bacterial growth, was considered for MIC. Each concentration was tested three times and the results were averaged.

\section{4. 2. Minimum Bactericidal Concentration (MBC)}

The minimum bactericidal concentration (MBC) is the lowest concentration at which an antimicrobial agent will kill a particular microorganism. The MBC is determined from broth dilution MIC tests by sub-culturing to agar plates that do not contain the test agent. The MBC is identified by determining the lowest concentration of antibacterial agent that reduces the viability of the initial bacterial inoculum by $\geq 99.9 \%$. $10 \mu \mathrm{L}$ of the content without turbidity wells was cultivated on the Muller-Hilton plate. The number of colonies was counted after $24 \mathrm{~h}$ at $37^{\circ} \mathrm{C}$. The first well which had equal or less than 3 colonies, was regarded as MBC. Antibacterial agents are usually regarded as bactericidal if the MBC is no more than three times of the MIC concentration.

\section{Results and Discussion}

\section{1. Characterization and Discussion}

In developing countries water pollution, especially industrial and agricultural effluents with high levels of toxicity, have been of serious concern. The progressive increase in environmental pollutants emerged the global search for novel, efficient and applicable compounds with high sorption capability. In the last decade macrocyclic supramolecules especially calixarene family, were introduced as a potential sensor for recognition and separation of toxic elements, including $\mathrm{Pb}^{2+}, \mathrm{Cd}^{2+}$ and $\mathrm{Hg}^{2+} \cdot{ }^{42-44}$ Among them, thiacalixarene and its derivatives having sulfur as an excellent auxiliary chelating agent in their structure have an effective interaction with transition metal cations. Incorporation of thiacalixarene in the backbone of the polymeric materials could help us to prepare such an interesting membrane with great applicability. Therefore, preparation of novel thermally stable polythiacalixamides (pTCAs) having flexible chelating cavity in their backbone and studying their potential capability in the extraction of transition metal ions particularly $\mathrm{Hg}^{2+}$ as hazardous cation is disclosed in this research. To have some reliable polymers with excellent cation extraction ability and high thermal stability, we decided to prepare polyamide with promising properties using para-tert-butylthiacalixarene dicarboxylic acid and commercial diamines. To achieve this goal, at first parent thiacalixarene was synthesized as revealed in the material section, using para-tert-butylphenol 

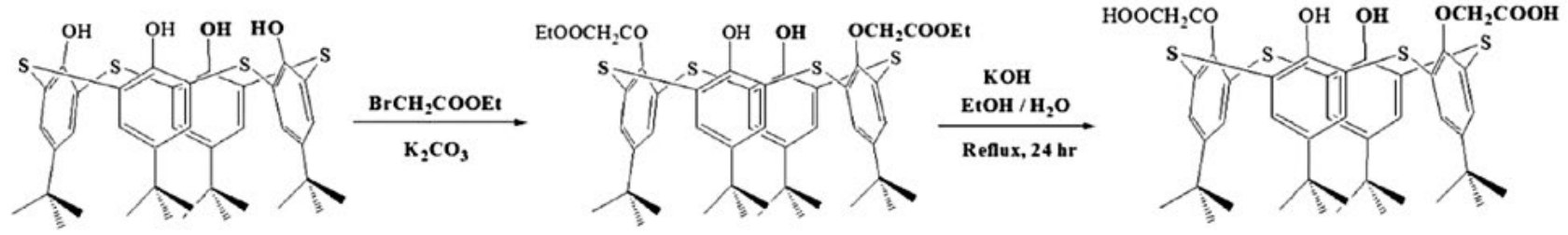

Scheme 1. Synthesis of thiacalix[4] arenedicarboxylic acid 3
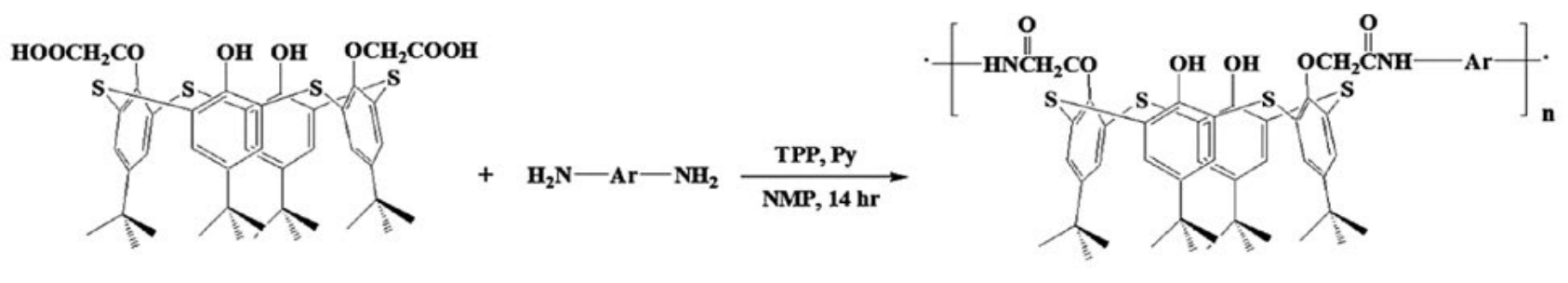

(3)

$\mathbf{A r}=$

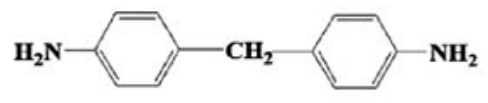

(A)

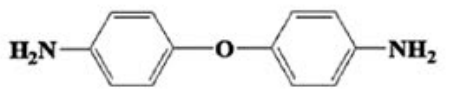

(C)<smiles>Nc1cccc2c(N)cccc12</smiles>

(B)

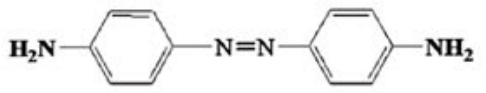

(D)

Scheme 2. Synthesis of polythiacalixamides pTCA A-D

and sulfur. Then it was functionalized with bromoethyl acetate to obtain the corresponding diester derivative and consequently the product was hydrolyzed using potassium hydroxide to give thiacalix[4]arene dicarboxylic acid as a functionalized monomer (Scheme 1). Then polythiacalixamides, pTCA A-D were obtained via direct polycondensation reaction of thiacalix[4] arene dicarboxylic acid 3 with various commercially available aromatic diamines using triphenylphosphite (TPP) and pyridine as condens- ing agents (Scheme 2). All the polymerization reactions afforded clear solutions which were cooled down and poured into the cold methanol while being stirred.

The structure and composition of the synthesized polyamides were characterized by a number of physico-chemical methods, i.e. ${ }^{1} \mathrm{H}$ NMR, IR, UV spectroscopy and elemental analysis. Also thermal stability and sorption capability of the pTCA A-D were determined and detailed completely in this article. ${ }^{1} \mathrm{H}$ NMR spectra of all the pre-

Table 1. FTIR and ${ }^{1}$ HNMR spectral data for the synthesized polythiacalixamides

\begin{tabular}{|c|c|c|c|c|c|c|}
\hline \multirow[t]{2}{*}{ Polymer } & \multicolumn{3}{|c|}{ FTIR (Absorption peaks) $\mathrm{cm}^{-1}$} & \multicolumn{3}{|c|}{${ }^{1} \mathrm{H}$ NMR (chemical shift) ppm } \\
\hline & $\mathrm{C}=\mathrm{O}$ & N-H & $\begin{array}{l}\text { important } \\
\text { peaks }\end{array}$ & $\begin{array}{c}\mathrm{N}-\mathrm{H} \\
\text { (amide proton) }\end{array}$ & $\begin{array}{c}\mathrm{CH}_{2} \\
\text { (aliphatic) }\end{array}$ & $\begin{array}{c}\text { Ar-H } \\
\text { (aromatic Proton) }\end{array}$ \\
\hline pTCA A & 1685 & 3360 & - & 12.75 & 4.58 & $6.90-7.88$ \\
\hline pTCA B & 1695 & 3355 & - & 12.10 & 4.97 & $7.05-7.95$ \\
\hline pTCA C & 1686 & 3368 & $1597(\mathbf{N}=\mathbf{N})$ & 12.47 & 4.56 & $7.08-7.95$ \\
\hline pTCA D & 1682 & 3351 & - & 12.31 & 4.63 & $7.11-7.86$ \\
\hline
\end{tabular}


Table 2. Elemental analysis (CHN) of polythiacalixamides

\begin{tabular}{lcccccc}
\hline Polymer & \multicolumn{3}{c}{ Calculated (\%) } & \multicolumn{3}{c}{ Found (\%) } \\
& C & H & N & C & H & N \\
\hline pTCA A & 70.35 & 6.19 & 4.68 & 70.02 & 6.01 & 4.72 \\
pTCA B & 68.94 & 5.92 & 5.02 & 68.61 & 5.72 & 4.98 \\
pTCA C & 66.77 & 5.72 & 9.16 & 66.21 & 5.54 & 8.90 \\
pTCA D & 68.11 & 5.84 & 4.67 & 67.86 & 5.57 & 4.43 \\
\hline
\end{tabular}

pared compounds clearly corresponded to the ascribed structures including monomer and polyamides by the number of signals and their multiplicities. Characteristic physical data of synthesized polymers are shown in Tables 1-3 and explained here in detail. Specified peaks in IR spectra of the polyamides at $1685,1695,1682$ and $1686 \mathrm{~cm}^{-1}$, respectively, indicate the characteristic stretching vibration of amidic carbonyl bonds of pTCA A-D. Amide proton (N$\mathrm{H})$ was also observed in ${ }^{1} \mathrm{H}$ NMR spectra of polyamides A-D around $\delta=12.4 \mathrm{ppm}$. The IR and ${ }^{1} \mathrm{H}$ NMR spectral data of the polythiacalixamides are summarized in Table 1.

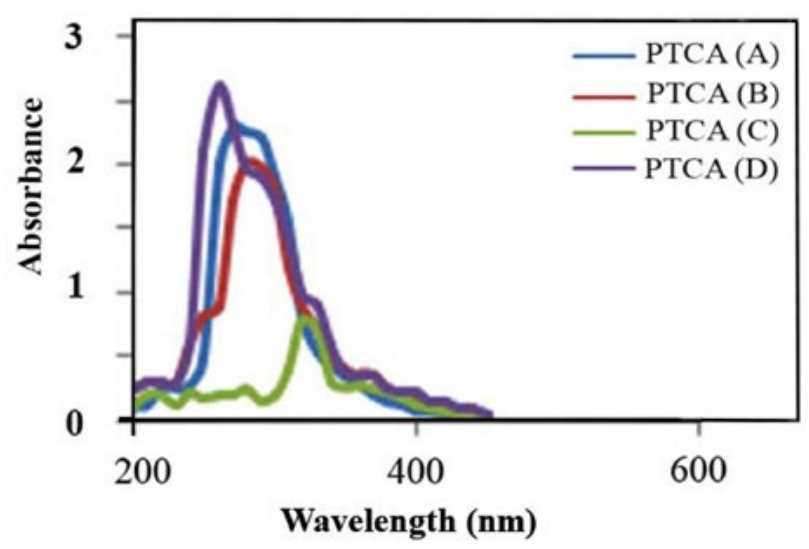

Fig. 1. UV Spectra of polythiacalixamides pTCA A-D

The study on photophysical characteristic of polythiacalixamides A-D was performed by UV-absorption spectroscopy and results are displayed as curves in Figure 1. The maximum of absorption wavelengths $\left(\lambda_{\max }\right)$ were observed at 270, 281, 323 and $262 \mathrm{~nm}$ for pTCA A-D, re- spectively. pTCA C has a noticeable $53 \mathrm{~nm}$ red shift compared to the other polymers due to the conjugation of $\mathrm{N}=\mathrm{N}$ group with phenyl rings in polymer chain.

To study on their applicability as a membrane in industry, considering the solubility in industrial solvent is essential. So, the solubilities of the pTCA A-D were investigated in variety of solvents and the results are represented in Table 3. The synthesized polyamides were soluble in aprotic polar solvents, such as NMP, DMF, DMSO, DMAc and in dioxane on heating. Existence of bulky thiacalixarene macrocycle in the backbone and creating free space between polymeric chains improved the solubility parameter relative to traditional polyamides. These polyamides were synthesized in high yields, with inherent viscosities in the range of $0.55-0.75 \mathrm{dL} / \mathrm{g}$ at $25^{\circ} \mathrm{C}$ in NMP, which are summarized in Table 3.

\section{2. Sorption of Heavy Metal Cations}

Functionalization of thiacalix[4]arenes especially at the lower rim makes them more effective as extractant. ${ }^{45-47,40}$ Hence, we investigated the preparation of a thiacalixarene derivative which has been functionalized at the lower rim and employed it in the backbone of the polymeric chain. Then we evaluated the transition metal ions sorption capability of these polymers by solid-liquid extraction procedure. Therefore, some metal cations with great importance from environmental view, such as $\mathrm{Cu}^{2+}$, $\mathrm{Co}^{2+}, \mathrm{Cd}^{2+}, \mathrm{Pb}^{2+}$ and $\mathrm{Hg}^{2+}$ were chosen and their aqueous solutions were treated with pTCAs A-D. The results including sorption percentage (S\%) and distribution coefficients $\left(K_{\mathrm{d}}\right)$ are illustrated in Tables $4-5$. From the results given in Tables 4 and 5 , it has been observed that pTCAs A-D have excellent extraction ability for $\mathrm{Hg}^{2+}, \mathrm{Pb}^{2+}, \mathrm{Cd}^{2+}$ and $\mathrm{Co}^{2+}$ from aqueous solution while exhibit some less promising capability toward $\mathrm{Cu}^{2+}$. In comparison with our recent studies on polycalixarenes (PCA), ${ }^{33-35}$ it is clear that the presence of four sulfur atoms at the bridge position enhances the complexation of thiacalixarene moieties with the larger size metal cations and results in reasonably higher sorption ability. Exact cavity size and tight complexation of thiacalixarene macrocycle with metal cations are the key factors for the observed higher efficiency (Scheme 3). The above mentioned parameters can also

Table 3. Solubility behavior and inherent viscosity of polythiacalixamides

\begin{tabular}{lccccccc}
\hline Polymer & DMF & DMAc & NMP & DMSO & Dioxane & Tetralin & $\boldsymbol{\eta}_{(\mathbf{d L} / \mathbf{g})^{\mathrm{a}}}$ \\
\hline pTCA A & $+\mathrm{h}$ & + & + & + & $+\mathrm{h}$ & - & 0.57 \\
pTCA B & $+\mathrm{h}$ & + & + & + & + & - & 0.75 \\
pTCA C & $+\mathrm{h}$ & + & + & + & $+\mathrm{h}$ & - & 0.55 \\
pTCA D & $+\mathrm{h}$ & + & + & $+\mathrm{h}$ & $+\mathrm{h}$ & - & 0.61 \\
\hline
\end{tabular}

+ , soluble at room temperature, $+\mathrm{h}$, soluble on heating; -, insoluble; DMF: $N, N$-dimethylformamide; DMAc: $N, N$-dimethylacetamide; NMP: $N$-methyl-2-pyrrolidone; DMSO: dimethyl sulfoxide; Tetralin:1,2,3,4-tetrahydronaphthalene. ${ }^{\mathrm{a}}$ Inherent viscosity was measured at a concentration of 0.5 $\mathrm{dL} / \mathrm{g}$ in NMP at $30^{\circ} \mathrm{C}$. 


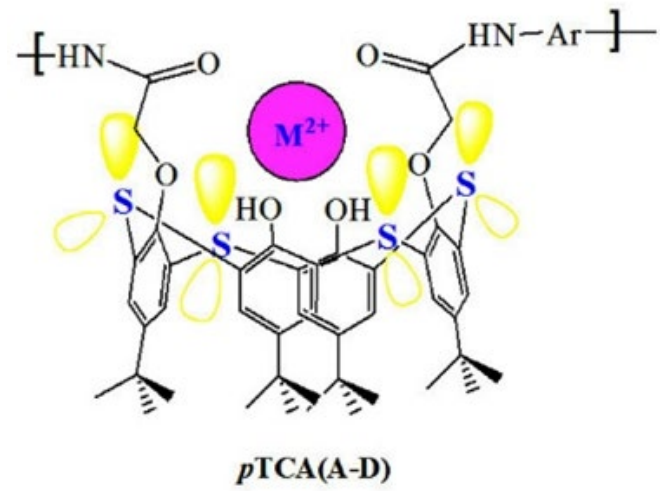

Scheme 3. Polythiacalixamide complexation with large cations

play an important role in the lower sorption capabilities of unfunctionalized monomeric calix and thiacalixarene as well as previously prepared polycalixarenes, relative to pTCAs A-D.

Table 4. Sorption percentage (S \%) of heavy metal cations by $p$ TCAs

\begin{tabular}{lccccc}
\hline Polymer & $\mathbf{H g}^{2+}$ & $\mathbf{P b}^{2+}$ & $\mathbf{C d}^{2+}$ & $\mathbf{C o}^{2+}$ & $\mathbf{C u}^{2+}$ \\
\hline pTCA A & 93.2 & 92.2 & 91.2 & 85.8 & 30.4 \\
pCA (CH $)$ & - & - & 41.8 & 40.9 & 53.7 \\
pTCA B & 90.0 & 89.5 & 93.2 & 80.0 & 57.3 \\
pCA (Naph.) & - & - & 38.7 & 36.3 & 36.7 \\
pTCA C & 93.3 & 92.3 & 90.0 & 83.1 & 59.3 \\
pCA (Azo) & - & - & 36.4 & 44.2 & 48.0 \\
pTCA D & 91.1 & 89.2 & 91.1 & 84.6 & 55.1 \\
pCA (Oxy) & - & - & 39.4 & 38.3 & 51.8 \\
\hline
\end{tabular}

Table 5. Distribution coefficients $\left(K_{\mathrm{d}}\right)$ of heavy metal cations by pTCAs

\begin{tabular}{lccccc}
\hline Polymer & $\mathbf{H g}^{2+}$ & $\mathbf{P b}^{2+}$ & $\mathbf{C d}^{2+}$ & $\mathbf{C o}^{2+}$ & $\mathbf{C u}^{2+}$ \\
\hline pTCA A & 5314.4 & 4728.2 & 4044.4 & 2416.9 & 174.6 \\
pTCA B & 3600.0 & 3409.5 & 5314.4 & 1600.0 & 536.7 \\
pTCA C & 5314.4 & 4600.1 & 3600.0 & 1966.8 & 582.8 \\
pTCA D & 4044.4 & 3303.7 & 4094.3 & 2197.4 & 488.9 \\
\hline
\end{tabular}

\section{2. 1. Sorption of Transition Metal Cations at Different $\mathbf{p H}$}

To evaluate the effect of $\mathrm{pH}$ on the sorption efficiency of pTCAs toward transition metal cations, some experiments have been performed in the $\mathrm{pH}$ range of 1.0 to 11 . It was found that at lower $\mathrm{pH}$ (up to $\mathrm{pH} 4.0$ ), cations, especially $\mathrm{Hg}(\mathrm{II})$, were in the free ionic form ${ }^{46}$ and the existing hydrogen cations $\left(\mathrm{H}^{+}\right)$will strongly compete with the transition metal ions for binding with unoccupied sites of pTCAs. Since, the active sites of pTCA, which consists of sulfur, hydroxyl and amide groups, are protonated in the presence of hydrogen cations. The strong electrical repul- sion prevents the metal cations to reach the complexation sites and will cause lower adsorption values. So, the lower adsorption efficiencies of pTCAs in strongly acidic media were expected. Surprisingly the removal efficiency increased at $\mathrm{pH}$ about 5 to 7 and decreased slightly at $\mathrm{pH}$ greater than 9. Maximum sorption efficiency in the $\mathrm{pH}$ range 5-7 for pTCA can be attributed to the more polarizabale characteristics of chelating groups of pTCAs. In this regard, the larger flexible thiacalixamide macrocyclic units can form more effective complexes with metal cations, particularly the larger ones, such as $\mathrm{Hg}(\mathrm{II})$ and $\mathrm{Pb}(\mathrm{II})$. It is worthy to mention that metal cations may precipitate with hydroxide ions at higher $\mathrm{pH}(\geq 9)$ and therefore slightly decreases in the adsorption results were normal. Therefore, neutral conditions were preferred for heavy metal removal experiments.

\section{3. Thermal Stability}

To explore the thermal stability of polythiacalixamides, thermal analyses including DSC and TGA were performed. The results, especially initial decomposition temperatures (IDTs) of pTCA A-D show that these polymers have considerable thermal stability. IDT data and other thermal properties such as $T_{\mathrm{g}}, T_{\max }$, char yields of the $\mathrm{pT}$ CAs A-D are also summarized in Table 6. The pTCAs showed glass transition temperatures $\left(T_{\mathrm{g}}\right)$, in the range of $157-178^{\circ} \mathrm{C}$ by DSC, which are meaningful owing to such bulky pendant groups. The increasing order of $T_{\mathrm{g}}$ corresponds to the increase in the order of rigidity and polarity of the polymer backbones. The relatively higher $T_{\mathrm{g}}$ value $\left(178^{\circ} \mathrm{C}\right)$ of pTCA B may be a result of structural stiffness caused by interchain forces between naphthalene units which solidify the polymer backbone and help polymer packing. The more solidity and better packing means the larger rotation barrier and less flexibility. The thermal stability of polyamides was evaluated by TGA in nitrogen atmosphere. The Figure 2 inset depicts a typical set of TGA curves for polyamide pTCA A-D in nitrogen. The decomposition temperatures $\left(T_{\mathrm{d}}\right)$ at $10 \%$ weight loss in nitrogen atmosphere were taken from the original TGA thermograms and are summarized in Table 6. All the polythiacalixamides exhibited good thermal stability. As evident in Table 6, the $10 \%$ weight loss of pTCAs A-D was in the range of $337-346^{\circ} \mathrm{C}$. The amounts of carbonized residues, char yields, were in the range of 39.1-58.5 wt $\%$ at $700{ }^{\circ} \mathrm{C}$ in nitrogen. The high char yields of these polyamides can be attributed to their high aromatic content. To survey more on the thermal characteristics of these polymers and to see the effect of sulfur atom on the thermal stability, comparison with the previously prepared $\mathrm{PCA}^{33}$ was performed. By considering the results mentioned in Table 6 , the thermal stability parameters (e.g. IDTs) of the synthesized polythiacalixamides relative to that of reference polyamides show negligible differences between these two series of polyamides. Polythiacalix- 
Table 6. Thermophysical properties of polythiacalixamides

\begin{tabular}{lccccc}
\hline Polymer & $\boldsymbol{T}_{\mathrm{g}}^{\mathrm{a}}$ & $\boldsymbol{T}_{\mathrm{ini}}^{\mathrm{b}}$ & $\boldsymbol{T}_{\mathbf{1 0 \%}}{ }^{\mathrm{b}}$ & $\boldsymbol{T}_{\max }^{\mathrm{c}}$ & $\begin{array}{c}\text { char yield } \\
\text { (wt \%) }\end{array}$ \\
\hline pTCA A & 160 & 276 & 337 & 385 & 58.5 \\
pCA (CH ${ }_{2}$ ) & 155 & 285 & 340 & 363 & 46 \\
pTCA B & 178 & 317 & 341 & 358 & 39.1 \\
pCA (Naph.) & 162 & 302 & 323 & 356 & 56.2 \\
pTCA C & 157 & 310 & 340 & 356 & 46.3 \\
pCA (Azo) & 157 & 312 & 353 & 369 & 49.9 \\
pTCA D & 161 & 324 & 346 & 354 & 32.9 \\
pCA (Oxy) & 152 & 328 & 352 & 368 & 47.8 \\
\hline
\end{tabular}

degradability and having very low permissible limit $(0.001$ $\mathrm{ppm}$ ) in drinking water, even trace amounts of $\mathrm{Hg}$ ions must be removed from aquatic systems. During last decades different methods have been developed to eliminate mercury in all forms involving elemental, inorganic and organic compounds. Different kinds of sorbents have been applied to meet this need and some of the recent and important sorbents are presented in Table 7. Most of them have some limitations, including temperature dependence, working $\mathrm{pH}$ range, time of contact etc. Herein, we introduce polythiacalix[4] amides as novel functionalized polyamides which have shown some promissing applicability

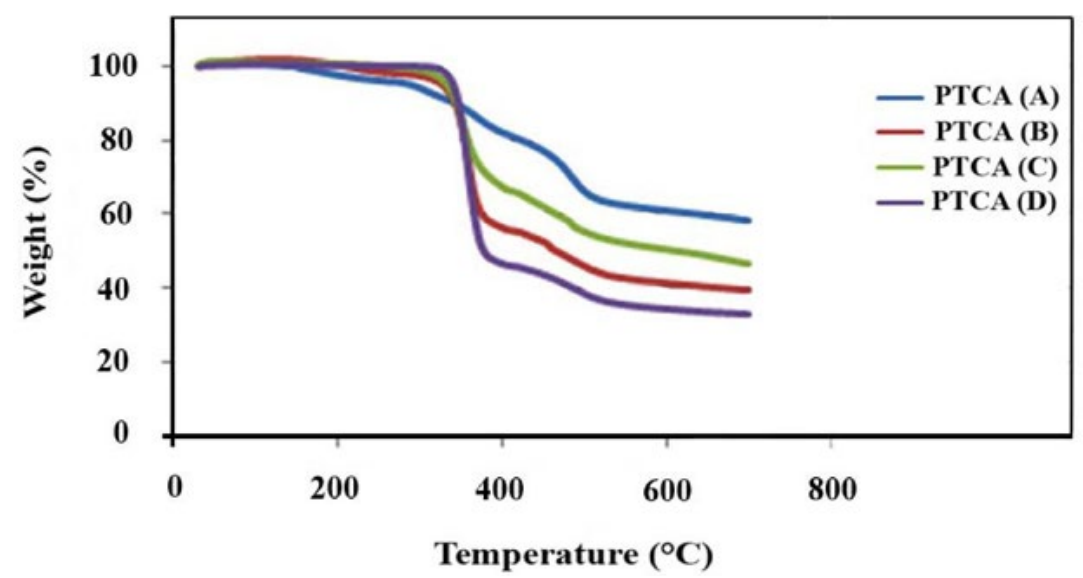

Fig. 2. TGA curves for polythiacalixamides pTCA A-D

amides showed slightly higher $T_{\mathrm{g}}$ values owing to unique features of sulfur atoms. Phenolic structures can rotate through the low energy barrier sulfur atoms to create different conformers prior to polymerization. So, as a result of low bulkiness of thiacalixarene, polythiacalixamides relative to polycalixamides with fixed methylene bridge groups and fixed cylindrical calixarene structures create lesser interchain cavity sizes and therefore more interchain forces will form. Thus, it is noteworthy to emphasize that polythiacalixamides due to the existence of polar coordinating sulfur atoms and adjustable conformers, represented high sorption capability, good solubility in industrial solvents and together with their significant thermal properties offer processability and applicability as a membrane.

\section{4. Overview on Mercury Removal}

Contamination of the environment with mercury which is naturally occurring in the earth's crust and released with volcanic activity as well as industrial activities, such as the burning of fossil fuels, ore processing, medical and municipal waste incineration, and the use of dental amalgams is a serious concern. Because of the hazardous characteristic of mercury, such as its high toxicity, non-bio- toward removal of some hazardous heavy metals, especially $\mathrm{Hg}$ (II) ions. As a result of acceptable thermal property and solubility as well as excellent sorption capability, pTCA can be employed in membrane technologies which focus on the reduction of mercury via recycling of $\mathrm{Hg}^{2+}$ from aqueous wastes and also reducing emissions from industrial activities.

\section{5. Antibacterial Evaluation}

The in vitro antibacterial activity of the synthesized polythiacalixamides against clinical isolates of Gram positive and Gram negative pathogens, such as Escherichia coli (ATCC 25922), Staphylococcus aureus (ATCC 25923), Klebsiella pneumoniae (NCTC 5056), Pseudomonas aeruginosa (1561) and Bacillus subtilis 1715 (PY79) bacterial strains was tested and compared with penicillin, ciprofloxacin and gentamicin as reference antibacterials. In these experiments, minimum inhibitory concentrations (MICs) and minimum bactericidal concentration (MBCs) were determined and their activities were interrelated by the known antibiotics penicillin, ciprofloxacin and gentamicin applied as known standards. The evaluation of the antibacterial properties demonstrated that the polymers showed acceptable inhibition capabilities at different levels which 
Table 7. Comparison of sorption efficiency of pTCA A with some of those reported in removal of mercury ions $\left(\mathrm{Hg}^{2+}\right)$

\begin{tabular}{|c|c|c|c|c|c|c|}
\hline Entry & Absorbents & $\begin{array}{l}\text { Quantity } \\
\text { of sorbent }\end{array}$ & $\begin{array}{l}\text { Concentration } \\
\text { of } \mathbf{H g}^{2+}\end{array}$ & Time & $\begin{array}{c}\text { Sorption } \\
\text { capability (\%) }\end{array}$ & Ref \\
\hline 1 & $\mathrm{FeS}_{2}$ (Pyrite), $\mathrm{N}_{2}$ atmosphere & $2 \mathrm{~g} / \mathrm{L}$ & $2 \mathrm{mg} \mathrm{L}^{-1}$ & $\begin{array}{l}(\mathrm{pH}: 4.1) 7 \mathrm{~d} \\
(\mathrm{pH}: 6.4) 2 \mathrm{~d} \\
(\mathrm{pH}: 10.4) 2 \mathrm{~h}\end{array}$ & 95 & {$[48]$} \\
\hline 2 & $\begin{array}{c}\text { Aluminum electrode } \\
\text { (electrocoagulation method) }\end{array}$ & $4 \mathrm{~cm} \times 1 \mathrm{~cm}$ & $2 \times 10^{-5} \mathrm{M}$ & $(\mathrm{pH} 7) 15 \mathrm{~min}$ & 99.85 & [49] \\
\hline 3 & $\begin{array}{c}\text { Iron electrode } \\
\text { (electrocoagulation method) }\end{array}$ & $4 \mathrm{~cm} \times 0.8 \mathrm{~cm}$ & $2 \times 10^{-5} \mathrm{M}$ & $(\mathrm{pH} \mathrm{7)} 15 \mathrm{~min}$ & 99.95 & {$[50]$} \\
\hline 4 & Thiacrown polymer & $20 \mathrm{mg} / 5 \mathrm{~mL}$ & $4-200 \mathrm{mg} \mathrm{L}^{-1}$ & $(\mathrm{pH} 1.5$ to 6.2$) 30 \mathrm{~min}$ & $>95$ & {$[51]$} \\
\hline 5 & Bamboo leaf powder & $4 \mathrm{~g} \mathrm{~L}^{-1}$ & $100 \mathrm{mg} \mathrm{L}^{-1}$ & $(\mathrm{pH} \approx 7) 60 \mathrm{~min}$ & 80 & {$[52]$} \\
\hline 6 & $\begin{array}{l}\text { Activated carbon prepared } \\
\text { from } C \text {. pentandra hulls }\end{array}$ & $200 \mathrm{mg} / 50 \mathrm{~mL}$ & $40 \mathrm{mg} \mathrm{L}^{-1}$ & $(\mathrm{pH} 6.0) 90 \mathrm{~min}$ & 99.7 & {$[48]$} \\
\hline 7 & $\begin{array}{l}\text { Activated carbon prepared } \\
\text { from } P \text {. aureus hulls }\end{array}$ & $225 \mathrm{mg} / 50 \mathrm{~mL}$ & $40 \mathrm{mg} \mathrm{L}^{-1}$ & $(\mathrm{pH} 7.0) 100 \mathrm{~min}$ & 98 & {$[48]$} \\
\hline 8 & $\begin{array}{l}\text { Activated carbon prepared } \\
\text { from C. arietinum waste }\end{array}$ & $300 \mathrm{mg} / 50 \mathrm{~mL}$ & $40 \mathrm{mg} \mathrm{L}^{-1}$ & $(\mathrm{pH} 7.0) 110 \mathrm{~min}$ & 96.29 & {$[48]$} \\
\hline 9 & $\begin{array}{l}\text { Thio chelating resin } \\
\text { (GMA-DVB) }\end{array}$ & $100 \mathrm{mg} / 100 \mathrm{~mL}$ & $5 \times 10^{-3} \mathrm{M}$ & (pH 5.8) $80 \mathrm{~min}$ & $\approx 100$ & {$[53]$} \\
\hline 10 & Thiol chelating resin (polystyrene) & $100 \mathrm{mg} / 20 \mathrm{~mL}$ & $400 \mathrm{mg} \mathrm{L}^{-1}$ & $(\mathrm{pH} 1.5) 8 \mathrm{~h}$ & $\approx 100$ & {$[54]$} \\
\hline 11 & $\begin{array}{l}\text { Bayberry tannin-immobilized } \\
\text { collagen fiber }\end{array}$ & $100 \mathrm{mg} / 100 \mathrm{~mL}$ & $200.0 \mathrm{mg} \mathrm{L}^{-1}$ & $(\mathrm{pH} 7.0) 24 \mathrm{~h}$ & 98.34 & {$[55]$} \\
\hline 12 & Hydrous manganese oxide & $100 \mathrm{mg} / 10 \mathrm{~mL}$ & $1.0 \times 10^{-8} \mathrm{~mol} \mathrm{~L}^{-1}$ & $(\mathrm{pH} 2.2) 30 \mathrm{~min}$ & 96.1 & {$[56]$} \\
\hline 13 & Hydrous tin oxide & $100 \mathrm{mg} / 10 \mathrm{~mL}$ & $1.0 \times 10^{-8} \mathrm{~mol} \mathrm{~L}^{-1}$ & $(\mathrm{pH} 2.2) 60 \mathrm{~min}$ & 93.1 & {$[56]$} \\
\hline 14 & Hydrous ferric oxide & $100 \mathrm{mg} / 10 \mathrm{~mL}$ & $1.0 \times 10^{-5} \mathrm{~mol} \mathrm{~L}^{-1}$ & $(\mathrm{pH} 8.68) 65 \mathrm{~min}$ & 62 & {$[57]$} \\
\hline 15 & Hydrous tungsten oxide & $100 \mathrm{mg} / 10 \mathrm{~mL}$ & $1.0 \times 10^{-5} \mathrm{~mol} \mathrm{~L}^{-1}$ & $(\mathrm{pH} 4.42) 95 \mathrm{~min}$ & 93.5 & {$[58]$} \\
\hline 16 & $\begin{array}{l}\text { Carbonaceous sorbent } \\
\text { from rice husk }\end{array}$ & $75 \mathrm{mg} / 100 \mathrm{~mL}$ & $200 \mathrm{mg} \mathrm{L}^{-1}$ & $(\mathrm{pH} 6) 120 \mathrm{~h}$ & $>90$ & [59] \\
\hline 17 & Chitosan-coated cotton fibers & $100 \mathrm{mg} / 25 \mathrm{~mL}$ & $0.008 \mathrm{~mol} \mathrm{~L}^{-1}$ & $(\mathrm{pH} \mathrm{5)} 20 \mathrm{~h}$ & $\approx 99$ & {$[60]$} \\
\hline 18 & Manganese dioxide nano-whiskers & $10 \mathrm{mg} / 100 \mathrm{~mL}$ & $10 \mathrm{mg} \mathrm{L}^{-1}$ & $(\mathrm{pH} \mathrm{5.5)} 1 \mathrm{~h}$ & $\approx 99$ & {$[60]$} \\
\hline 19 & $\begin{array}{l}\text { Poly(acrylic acid) modified } \\
\text { seed gum }\end{array}$ & $100 \mathrm{mg} / 20 \mathrm{~mL}$ & $100 \mathrm{mg} \mathrm{L}^{-1}$ & $(\mathrm{pH} \mathrm{6)} 4 \mathrm{~h}$ & 92.36 & {$[61]$} \\
\hline 20 & Polythiacalix[4]amides & $25 \mathrm{mg} / 10 \mathrm{~mL}$ & $10 \times 10^{-3} M$ & $(p H 7) 3 h$ & 93.2 & - \\
\hline
\end{tabular}

was necessary for being incorporated in food and medical industeries. The MIC was the lowest concentration with no visible growth. The growth of bacteria was observed in the cells with lower concentrations than MIC. The solutions with no visible growth were then spread on agar plates and incubated at $37^{\circ} \mathrm{C}$ for $24 \mathrm{~h}$ to obtain MBC values.

The good activity can be attributed to the presence of pharmacologically active thiacalixarenes which are constituent part of the polymeric backbone. Also this result can probably be ascribed to the high-value nucleophilic characteristics of sulfur atoms which could modify the electronic density in the polymeric chains and thereby in- fluence the absorption, distribution and metabolism of the bioactive molecules.

The mentioned antibiotics were evaluated for their antibacterial activity against standard bacteria strains according to table CLSI (2011). Results are presented in Table 8 . As can be seen, all of the standard samples were very sensitive against ciprofloxacin antibiotic. The lowest MIC was recorded for $E$. coli which was about $0.015 \mu \mathrm{g} / \mathrm{mL}$. However, $B$. subtilis and $S$. aureus were sensitive toward gentamicine and penicillin antibiotics according to antimicrobial measurements data given in Table 8 . The MBC results show that examined antibiotics were so much effective toward the 
Table 8. Comparison of in vitro antibacterial activities of the synthesized polymers, monomers and known antibiotics after $24-48 \mathrm{~h}, \mathrm{conc} . \mu \mathrm{g} / \mathrm{mL}$

\begin{tabular}{|c|c|c|c|c|c|c|c|c|c|c|}
\hline \multirow[t]{3}{*}{ Bacteria Polymer } & \multicolumn{6}{|c|}{ Gram negative } & \multicolumn{4}{|c|}{ Gram positive } \\
\hline & \multicolumn{2}{|c|}{$\begin{array}{c}\text { Escherichia } \\
\text { coli }\end{array}$} & \multicolumn{2}{|c|}{$\begin{array}{c}\text { Pseudomonas } \\
\text { aeruginosa }\end{array}$} & \multicolumn{2}{|c|}{$\begin{array}{c}\text { Klebsiella } \\
\text { pneumoniae }\end{array}$} & \multicolumn{2}{|c|}{$\begin{array}{l}\text { Bacillus } \\
\text { subtilis }\end{array}$} & \multicolumn{2}{|c|}{$\begin{array}{c}\text { Staphylococcus } \\
\text { aureus }\end{array}$} \\
\hline & MIC & MBC & MIC & MBC & MIC & MBC & MIC & MBC & MIC & MBC \\
\hline pTCA A & 125 & 250 & 250 & $>250$ & 250 & $>250$ & 31.2 & 125 & 62.5 & 125 \\
\hline pTCA B & 187.5 & 375 & $>375$ & - & 187.5 & $>375$ & 375 & $>375$ & 375 & $>375$ \\
\hline pTCA C & $>250$ & - & $>250$ & - & $>250$ & - & $>250$ & - & 250 & $>250$ \\
\hline Penicillin & 8 & $>8$ & $>8$ & - & $>8$ & - & 0.125 & 0.5 & 0.062 & 0.125 \\
\hline Ciprofloxacin & 0.015 & 0.062 & 0.062 & 0.125 & 0.031 & 0.062 & 0.031 & 0.125 & 0.031 & 0.062 \\
\hline Gentamicin & 4 & 8 & $>128$ & - & $>128$ & - & 4 & 8 & 0.5 & 1 \\
\hline
\end{tabular}

mentioned microorganisms. Antibacterial experiments indicated that these polymers have displayed some reliable bactericidal efficiency in high concentrations. On the other hand, in vitro antibacterial assay of the synthesized polycalixamides A-C exhibited acceptable activities against all Gram positive and Gram negative strains tested. pTCA D was removed from these experiments due to its low solubility which was necessary for micro dilution procedure. Even though the synthesized pTCA A-D were not in the range of the known commercial antibiotics mentioned above, we can still achieve some antibacterial applicability with using these polymers in the next generation of industrial food and medical appliances or in coating equipments which need high thermal stability, acceptable solubility for processing, and reliable antimicrobial characteristic at the same time.

\section{Conclusions}

In macromolecular science it has been proved that calixarene-based ionophores have great acceptability in modern chemistry because of their extreme capability in functionalization from bridge position up to the rims. Therefore, we have taken the advantage of these structures for preparation of ion-selective as well as antibacterial polymers to suggest novel formulations for producing antibacterial membranes. Hence, the main goal of this work is to achieve polyamides with potential great sorption capability which could be applied in polymeric sorbents and membranes. Moreover, preparation of antibacterial polyamides which have both antibacterial characteristics and also high temperature bearing capacity was the other goal of this study. So, these ambitions were accomplished by incorporation of thiacalixarene moiety into the polyamide chains via polycondensation of thiacalixarene dicarboxylic acid with commercial diamines. The performed experiments demonstrated the characteristic features, such as solubility in organic solvents, photophysical behavior, thermal stability and sorption capabilities of polythiacalixamids, besides their reliable and valuable antibacterial properties. Among them, high extraction efficiencies toward $\mathrm{Hg}^{2+}, \mathrm{Pb}^{2+}, \mathrm{Cd}^{2+}$ and $\mathrm{Co}^{2+}$ was exceptional and they seem to be good choices for additional sorption studies in the future. These polyamides bearing unique structure of thiacalixarene with precisely oriented amide functionality and sulfur atoms, provide excellent complexation site for the cations and of course for interaction with cell walls of Gram positive and negative pathogens. Moreover, their intrinsic thermal stability and favorable solubility makes them potentially applicable for advanced industrial purposes and in fabricating medical appliances.

\section{Acknowledgments}

The financial supports by Babol University of medical sciences as well as Research Council of Mazandaran University are gratefully acknowledged. Also we should appreciate Fariba Asgharpour (M.Sc.) for helping us in the evaluation of antibacterial characteristics.

\section{References}

1. J. Luo, Y. S. Zheng, Curr. Org. Chem. 2017, 16, 483-506. DOI: $10.2174 / 138527212799499813$

2. K. Gloe, Macrocyclic chemistry (Current trends and future perspectives), Kluwer Academic Publishers, Dordrecht, 2005.

3. W. Walkowiak, C.A. Kozlowski, Desalination 2009, 240, 186197. DOI:10.1016/j.desal.2007.12.041

4. J. W. Steed, J. L. Atwood, Supramolecular Chemistry, second ed. Wiley, New York, 2009. DOI:10.1002/9780470740880

5. O. H. Rubio, R. Taouil, F. M. Muñiz, L. M. Monleón, L. Simón, F. Sanz, J. R. Morán, Org. Biomol. Chem. 2017, 15, 477-485. DOI:10.1039/C6OB02237E

6. S.B. Maamar, N. Jadambaa, F. Vocanson, F. Meganem, C. Felix, I. Dumazet-Bonnamour, J. Supramol. Chem. 2009, 21, 450-454. DOI:10.1080/10610270802195586

7. S. Sayin, F. Ozcan, M. Yilmaz, Desalination 2010, 262, 99-105. DOI:10.1016/j.desal.2010.05.053

8. R. Ebdelli, A. Rouis, J. Davenas, I. Bonnamour, H. Ben Ouada, Sensor Lett. 2011, 9, 2241-2244. DOI:10.1166/sl.2011.1779

9. S. Sayin, M. Yilmaz, Desalination 2011., 276, 328-335. DOI:10.1016/j.desal.2011.03.073

10. I. Akin, S. Erdemir, M. Yilmaz, M. Ersoz, J. Hazard. Mat. 2012, 223-224, 24-30. DOI:10.1016/j.jhazmat.2012.03.043 
11. J. W. Steed, P.A. Gale, Supramolecular chemistry: from molecules to nanomaterials, John Wiley \& Sons, Ltd. New York, 2012.

12. S. M. Baghbanian, Y. Babajani, H. Tashakkorian, S. Khaksar, M. Farhang, C. R. Chim. 2013, 16, 129-134.

DOI:10.1016/j.crci.2012.10.014

13. M. M. Lakouraj, H. Tashakkorian, M. Rouhi, Chem. Sci. Trans. 2013, 2, 739-748.

14. B. Genorio, Acta Chim. Slov. 2016, 63, 496-508.

DOI:10.17344/acsi.2016.2289

15. Z. D. Ghezelbash, K. A. Dilmaghani, Acta Chim. Slov. 2016, 63, 790-797.

16. M. D. Shah, Y. K. Agrawal. Calixarene: A new architecture in the pharmaceuticals, J. Sci. Indust. Res. 2012, 71, 21-26.

17. D. Reinhoudt, Supramol. Chem. 2016, 28, 342-350. DOI:10.1080/10610278.2015.1109326

18. S. L. Debbert, B. D. Hohand, D. J. Dulak, J. Chem. Educ. 2016, 93, 372-375. DOI:10.1021/acs.jchemed.5b00641

19. F. Zhang, Y. Sun, D. Tian, W. S. Shin, J. S. Kim, H. Li, Chem. Commun. 2016, 52, 12685-12693.

DOI:10.1039/C6CC05876K

20. R. Lamartine, C. Bavoux, F. Vocanson, A. Martin, G. Senlis, M. Perrin, Tetrahedron Lett. 2001, 42, 1021-1024.

DOI:10.1016/S0040-4039(00)02131-6

21. S. Bouhroum, F. Arnaud-Neu, Z. Asfari, J. Vicens, J. Supramol. Chem. 2005, 17, 629-635.

DOI:10.1080/10610270500211693

22. Y. K. Agrawal, J. P. Pancholi, Ind. J. Chem. 2007, 46A, 13731382.

23. A. Zaghbani, R. Tayeb, M. Dhahbi, M. Hidalgo, F. Vocanson, I. Bonnamour, P. Seta, C. Fontàs, Sep. Purif. Technol. 2007, 57, 374-379. DOI:10.1016/j.seppur.2007.03.025

24. Y. Li, X. Hu, X. Song, T. Sun, Environ. Poll. 2012, 167, 93-100. DOI:10.1016/j.envpol.2012.03.042

25. A. Akdoğan, M. Deniz, S. Cebecioglu, A. Sen, H. Deligöz, Sep. Sci. Technol. 2002, 37, 973-980. DOI:10.1081/SS-120002226

26. E. A. Shokova, V. V. Kovalev, Russ. J. Org. Chem. 2002, 39, 1-28. DOI:10.1023/A:1023416409935

27. H. Deligöz, J. Incl. Phenom. 2006, 55, 197. DOI:10.1007/s10847-006-9096-Z

28. M. H. Patel, V. B. Patel, P. S. Shrivastav, Tetrahedron 2008, 64, 2057-2062. DOI:10.1016/j.tet.2007.12.048

29. M. Tabakci, M. Yilmaz, Bioresour. Technol. 2008, 99, 66426655. DOI:10.1016/j.biortech.2007.11.066

30. H. Deligöz, S. Memon, Pak. J. Anal. Environ. Chem. 2011, $12,1-24$.

31. B. Dizman, M. O. Elasri, L. J. Mathias, J. Appl. Polym. Sci. 2004, 94, 635-642. DOI:10.1002/app.20872

32. G. Thenmozhi, D. Jaya Kumar, M. Gopalswamy, R. Jaya Santhi, Pharma. Chem. 2011, 3(6), 325-333.

33. M. M. Lakouraj, H. Tashakkorian, J. Macromol. Sci. Part A, 2012, 49, 806-813. DOI:10.1080/10601325.2012.714318

34. M. M. Lakouraj, H. Tashakkorian, J. Macromol. Sci. Part A, 2013, 50, 310-320. DOI:10.1080/10601325.2013.755859

35. M. M. Lakouraj, H. Tashakkorian, J. Supramol. Chem. 2013, 25, 221-232. DOI:10.1080/10610278.2012.758366

36. V. Hasantabar, M. M. Lakouraj, H. Tashakkorian, M. Rouhi,
Des. Monomers Polym. 2016, 19, 607-618.

DOI:10.1080/15685551.2016.1187440

37. D. D. Perrin, W. L. F. Armarego, Purification of laboratory chemicals, Pergamon Press, Oxford, UK, 1988.

38. H. Kumagai, M. Hasegawa, S. Miyanari, Y. Sugawa, Y. Sato, T. Hori, S. Ueda, H. Kamiyama, S. Miyano, Tetrahedron Lett. 1997, 38, 3971-3972. DOI:10.1016/S0040-4039(97)00792-2

39. T. Sone, Y. Ohba, K. Moriya, H. Kumada, K. Ito, Tetrahedron 1997, 53, 10689-10698.

DOI:10.1016/S0040-4020(97)00700-X

40. B. Masci, Z. Asfari, V. Böhmer, J. Harrowfield, J. Vicens, Calixarenes 2001, Kluwer Academic Publishers, Dordrecht, Netherlands, 2001, 235-249.

41. C. R. Mahon, D. C. Lehman, G. Jr. Manuselis, Textbook of diagnostic microbiology, Elsevier Health Sciences, London, 2014.

42. A. F. Danil De Namor, W.B. Aparicio-Aragon, M. T. Goitia, A. R. Casal, J. Supramol. Chem. 2004, 16, 423-433. DOI:10.1080/10610270410001721944

43. V. Arora, H. M. Chawla, S. P. Singh, Arkivoc 2007, (ii), 172200.

44. I. I. Abbas, J. K. Chaaban, J. Supramol. Chem. 2012, 24, 213 219. DOI:10.1080/10610278.2011.643795

45. C. Wieser, C. B. Dieleman, D. Matt, Coord. Chem. Rev. 1997, 165, 93-161. DOI:10.1016/S0010-8545(97)90153-3

46. C. D. Gutsche, Calixarenes revisited, Royal Society of Chemistry, Cambridge, 1998.

47. D. M. Roundhill, H. F. Koch, Chem. Soc. Rev. 2002, 31, 60-67. DOI:10.1039/b003141k

48. M. M. Rao, Reddy D. H. K. Kumar, P. Venkateswarlu, K. Seshaiah, J. Environ. Manage. 2009, 90, 634-643.

DOI:10.1016/j.jenvman.2007.12.019

49. J. Bower, K. S. Savage, B. Weinman, M. O. Barnett, W. P. Hamilton, W. F. Harper, Environ. Pollut. 2008, 156, 504-514. DOI:10.1016/j.envpol.2008.01.011

50. C. P. Nanseu-Njiki, S. R. Tchamango, P. C. Ngom, A. Darchen, E. Ngameni, electrodes, J. Hazard. Mat. 2009, 168, 14301436. DOI:10.1016/j.jhazmat.2009.03.042

51. T. F. Baumann, J. G. Reynolds, G. A. Fox, React. Funct. Polym. 2000, 44, 111-120.

DOI:10.1016/S1381-5148(99)00085-1

52. D. K. Mondal, B. K. Nandi, M. K. Purkait, J. Environ. Chem. Eng. 2013, 1, 891-898. DOI:10.1016/j.jece.2013.07.034

53. A. A. Atia, A. M. Donia, A. M. Yousif, React. Funct. Polym. 2003, 56, 75-82. DOI:10.1016/S1381-5148(03)00046-4

54. L. Joseph, V. N. S. Pillai, Environ. Pollut. 1987, 48, 213-222. DOI:10.1016/0269-7491(87)90035-2

55. X. Huang, X. Liao, B. Shi, J. Hazard. Mat. 2009, 170, 11411148. DOI:10.1016/j.jhazmat.2009.05.086

56. S. P. Mishra, S. S. Dubey, D. Tiwari, J. Colloid Interface Sci. 2004, 279, 61-67.

57. S. P. Mishra, (Miss) Vijaya, J. Colloid Interface Sci. 2006, 296, 383-388. DOI:10.1016/j.jcis.2005.11.040

58. E. I. El-Shafey, J. Hazard. Mat. 2010, 175, 319-327. DOI:10.1016/j.jhazmat.2009.10.006

59. R. Qu, C. Sun, F. Ma, Y. Zhang, C. Ji, Q. Xu, C. Wang, H. Chen, 
J. Hazard. Mat. 2009, 167, 717-727.

DOI:10.1016/j.jhazmat.2009.01.043

60. K. P. Lisha, S. M. Maliyekkal, T. Pradeep, Chem. Eng. J. 2010,
160, 432-439. DOI:10.1016/j.cej.2010.03.031

61. V. Singh, S. K. Singh, S. Maurya, Chem. Eng. J. 2010, 160, 129-137. DOI:10.1016/j.cej.2010.03.020

\section{Povzetek}

Politiakaliks[4]amidi so nova kategorija poliamidov z velikimi sorpcijskimi sposobnostmi za nekatere okoljsko nevarne kovinske ione, zlasti $\mathrm{Hg}^{2+}$. Pripravili smo jih s pomočjo direktne sinteze s polikondenzacijskim protokolom $\mathrm{z}$ uporabo tiakaliks[4] aren dikarboksilne kisline in komercialnih diaminov. Poliamide, ki so nastali na ta način, smo izolirali z visokimi izkoristki; njihove viskoznosti so bile v območju $0.55-0.75 \mathrm{dl} / \mathrm{g}$. Fotofizične lastnosti smo določili z merjenjem valovne dolžine $\mathrm{z}$ maksimalno absorpcijo za vsak polimer s pomočjo UV absorpcijske spektroskopije. Termogravimetrične analize so pokazale visoko termično stabilnost teh poliamidov v območju od 337 do $346^{\circ} \mathrm{C}$, kjer je prišlo do 10 $\%$ izgube mase; izkoristki oglja na koncu so bili pri $600^{\circ} \mathrm{C} 32.9-58.5 \%$. Temperature steklastega prehoda so bile med 157 in $178^{\circ} \mathrm{C}$. Da bi raziskali možne sorpcijske lastnosti teh politiakaliksamidov, smo iz odpadnih voda izvedli ekstrakcijo trdno-tekoče nekaterih strupenih ionov kovin prehoda, kot so $\mathrm{Cu}^{2+}, \mathrm{Co}^{2+}, \mathrm{Cd}^{2+}, \mathrm{Pb}^{2+}$ in $\mathrm{Hg}^{2+}$. Antibakterijske študije smo izvedli z Gram pozitivnimi in Gram negativnimi bakterijami ter dobili nekatere obetajoče rezultate, ki kažejo na možnost uporabe teh politiakaliksamidov kot sestavin za industrijske antibakterijske membrane. 